\title{
Protection and Safety of the Application of Radiation Sources in Medicine
}

\author{
TISZOLCZI Balázs Gergely
}

\begin{abstract}
Since the discovery of the $X$-ray and radioactivity the largest user of radiation sources is medicine. That is the reason why the end of the 19th century and the be-ginning of the 20th century brought significant changes in healing, compared to the previous ones. After Wilhelm Conrad Röntgen - the latter Nobel Prize winning physicist - discovered X-rays they were named after him, and mankind's desire to be able to "see into" the interior of the human body became a reality.
\end{abstract}

\section{Introduction}

After its discovery, the medical diagnostic application of X-rays rapidly spread because of their great importance. At the same time, especially in military field conditions, an increasing number of physicians and their patients suffered from more or less radiation exposure, the damaging effects of which on living tissues became widely known only years later, after some tragic events. In the years following the revolutionary realization of Röntgen, several discoveries of similar significance happened. In 1896 Becquerel discovered radioactivity, the Curies discovered polonium in 1898, Becquerel discovered $\alpha$ and $\beta$ radiation in 1900 and Vil- lard discovered $\gamma$ radiation, which are summarisingly called ionizing radiation, based of their physical effects on materials. In the course of experiments made with radioactive materials, scientists experienced that the radiation of materials is similarly harmful to X-rays. (Fehér, Deme [ed.], 2010: 17-18) The early reactions of tissues after high-dose exposure, e.g. skin redness, became obvious early on. However, it took experts a long time, several years, to realise the risks of cancer varieties caused by long term damage, e.g. ionising radiation, the effects of which incubate for a long time, and low-dose radiation which accumulates even after the recovery of the tissue without any trace and does not cause any other tissue reactions. Some decades later epidemiological analyses proved without doubt that ionising radiation does increase the incidence of cancer. (Fehér, Deme [ed.], 2010: 65) After the reali- zation, radiation protection gradually became more emphasized in technological applications in addition to properly tailored technical protection, strict, administrative and organizational security measures, which are still essential conditions for the applicability of the radiation sources. During the first, almost fiftyyear long period of radiation protection, the misuses of radioactive sources had hundreds of victims. Thanks to today's techniques and the develop- ment of radiation protection as a field of science the much more widely used sources cause far fewer tragic events. (Fehér, Deme [ed.], 2010: 22)

1 National University of Public Service, Budapest, Hungary, tiszolczi.balazs@ gmail.com

TISZOLCZI Balázs Gergely: Protection and Safety of the Application of Radiation Sources in Medicine

All things considered, mankind has been affected by significant radiation exposure orig- inating from artificial sources since the very end of the 19th century. However, ionising radiation does not reach the population just because of technological development, as the biosphere has always been exposed to radiation coming from natural sources. (MVM, 2013) Most of thse so called natural radiation sources maintain a background radiation. The one source of background radiation is the high-energy cosmic radiation coming from the Uni- verse and the others are the natural radioactive isotopes $\left({ }^{40} \mathrm{~K},{ }^{238} \mathrm{U},{ }^{232} \mathrm{Th}\right)$ existing in the Earth's crust, with half- 36 eqiods of billions of years for their fission products. (Fehér, Deme [ed.], 2010: 429) The division and the scale of the exposure descending from natural and artificial radiation sources and reaching the population is introduced on Table 1.

\begin{tabular}{|l|l|}
\hline Natural & $\mathbf{( 2 , 4} \mathbf{~ m S v} /$ year $)$ \\
\hline cosmic external & $0,3 \mathrm{mSv} / 10,26 \%$ \\
\hline cosmic internal & $0,015 \mathrm{mSv} / 0,53 \%$ \\
\hline crust external & $0,5 \mathrm{mSv} / 17,70 \%$ \\
\hline crust internal & $1,6 \mathrm{mSv} / 56,63 \%$ \\
\hline Artificial & $\mathbf{( 0 , 4} \mathbf{~ m S v} / \mathbf{y e a r})$ \\
\hline nuclear industry & $0,0002 \mathrm{mSv} / 0,01 \%$ \\
\hline medicine & $0,4 \mathrm{mSv} / 14,16 \%$ \\
\hline
\end{tabular}




\section{Fall - out radiation (atomic tests) $\quad 0,01 \mathrm{mSv} / 0,35 \%$ \\ Table 1 (MVM, 2013) \\ The annual average radiation exposure on the Earth's population per capita in effective doses and \\ the percentage of man's radiation exposure from various sources}

As it seems in Table 1, 97 per cent of all the artificial radiation exposure for the Earth's population is caused by irradiation for medical purposes (MVM, 2013) In Hungary, the aver- age natural radiation exposure per capita is $3 \mathrm{mSv}$ a year, whereas, the average exposure per capita coming from artificial sources is about $1 \mathrm{mSv}$ a year, which almost exclusively derives from medical sources. Nearly everybody has already encountered medical radiation expo- sure, especially when the number of X-ray examinations is very high. Due to the proportion of the examinations' frequency, approximately $90 \%$ of the medical radiation exposure on the domestic population is exposure to X-ray diagnostics and $10 \%$ is exposure to isotope diagnostics. In harmony with this data, most people work in the medical X-ray departments from the working areas applying ionising radiation, but the number of those employed in nu- clear medicine and in radiation therapy is also quite significant. Physicians or other experts of health care such as medical physicists ask for or carry out examinations and have a determin- ing role in choosing the measure and the way the radiation exposure affects patients, and in keeping the risks to health under control. (Fehér, Deme [ed.], 2010: 449) However, not only patients' appropriate protection, but also that of the persons taking care of them and working in the effective range has to be assured. The character of the multiple risks originating from the use of radiation sources means significant tasks for the specialists of occupational safety working in health care. The reason for that is the fact that ionizing radiation sources and

TISZOLCZI Balázs Gergely: Protection and Safety of the Application of Radiation Sources in Medicine

equipment producing ionizing radiation are considered to be critical applications from the viewpoint of human health and safety in medical practice.

The users and those persons who are responsible for safety have to acquire and apply numerous personal, administrative and physical-technical specifications and requirements besides the basic knowledge of technology and radiation protection. To do so - together with the magisterial and decision maker's activity — they have to keep risks at the lowest level possible.

In this article I do not want to give detailed descriptions about all the necessary conditions of safety use and protection. My only goal is to provide an overall review - through the rele- vant laws, standards, magisterial recommendations and guidelines - about the organization- al, human and technical information that should be fully known by those who are responsible for protective operations in order to suit the requirements coming from comprehensive safety challenges of the use of ionizing radiation.

\section{In a few words about ionizing radiation ${ }^{2}$}

A chemical element is determined by the number of protons of unit positive charge to be found in the nucleus. Besides the protons, electrically neutral neutrons build up a nucleus. In the various nuclei of a certain chemical element the number of protons is always determined, at the same time; the number of neutrons may vary. Atoms have various neutron numbers, but the same proton numbers of the isotopes of a chemical element are determined by the num- ber of protons. Isotopes can be either stable or instable. Instable atoms are called radioactive isotopes. A stable nucleus does not dissolve and does not emit any radiation. The reason why an instable nucleus is instable is that it can get into a stable or more stable state through a ra- dioactive transformation. In Nature, spontaneous processes always come off towards greater stability. Every element has radioactive isotopes; what is more, their number is far higher than that of stable isotopes. Radioactive isotopes dissolve spontaneously. In the meantime, they emit radioactive radiation. This process is called radioactivity. Unstable elements that emit radioactive particles or energy are called parent elements and the emerging ones are termed daughter elements. ${ }^{3}$

Three types of radioactive (ionizing) radiation are known and two of them are used in medical practice. They are

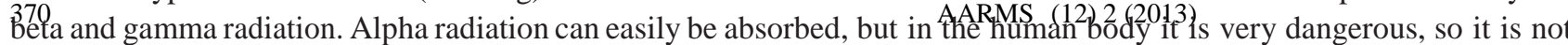
applied in medicine. During alpha decay an alpha particle is released from the nucleus which consists of two protons and two neutrons (helium nucleus). This kind of transformation is typical of elements with a large mass number. Another characteristic of alpha radiation is the short range of absorption so as an external source of radiation it is less dangerous to the human body. It can be absorbed in the upper skin layer or in the air at a few centimetres distance. From the point of view of protection the most important task is to prevent it from getting inside the body, as it can cause massive damage due to its large ionizing ability.

2 The content of this chapter is based on a note from the homepage of Paks Nuclear Power Plant. http://www.atomeromu.hu/download/3217/Alapfokozatu_sugarvedelmi_ismeretek_jegyzet.pdf (downloaded: 0108 2013)

3 A daughter element often becomes a parent element in the course of a subsequent decay. 
Beta radiation is formed during beta decay of nuclei. Two types of them are known. The negative beta decay, in which there are high energy electrons and the positive one, when positrons leave the nucleus. The ionizing ability of beta radiation is smaller than that of the above-described alpha radiation, so it has a larger penetration ability that can range from some centimetres to 10-15 meters in the air, depending on its energy. Its effective range is a few millimeters in human tissues. We can easily protect ourselves against it, putting a plexi- glass between the source of radiation and its user.

Gamma radiation consists of high-frequency electromagnetic waves that are formed when a nucleus transits from an excited state to a lower one. This is the so called gamma de-cay. The protection against it is possible by using elements of high atomic weight and density (usually: lead).

$\mathrm{X}$-radiation, similarly to gamma radiation, is also a type of electromagnetic radiation. The beam particles of electromagnetic radiation are called photons. In interactions a gam- ma-ray photon and an X-ray photon behave exactly the same way. The difference is that gamma radiation derives from the nucleus, while $\mathrm{X}$-radiation is formed on electron shells. Depending on the mechanism of the formation we can speak about braking or a characteristic type of $\mathrm{X}$ radiation. The first one is generated by braking electrons, while the other is formed after ionizing an electron on an inner electron shell.

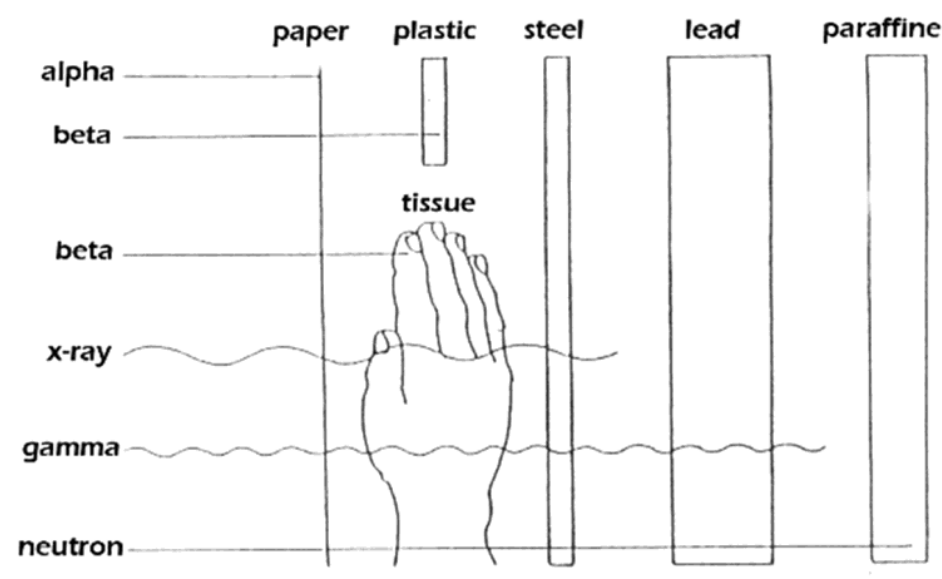

Figure $1^{4}$ Absorption and penetrating capability of ionizing radiations

Workplaces and technologies using ionizing radiation sources cause health hazards to living organisms of various types and at various degrees. A lot of serious health-damaging radiation effects are well known and caused by the nature of the radiation and its mode of action within a living entity. The most remarkable are as follows: burns, some types of cancer, development of different mutations or leukemia. The effects on health are generally divided into two main sections: radiation injury occurs when only some organs or tissues of the body are damaged and radiation sickness occurs when the whole organism suffers from those impacts. An additional partition criterion can be the time of emergence of the symp- toms, which may be an early one (they can be seen within hours or days) or a late one when

4 http://www.atomeromu.hu/download/3217/Alapfokozatu_sugarvedelmi_ismeretek_jegyzet.pdf (downloaded: 0108 2013)

TISZOLCZI Balázs Gergely: Protection and Safety of the Application of Radiation Sources in Medicine

years or decades elapse before the presence of the effects. In addition, the health effects of the radiation can be somatic (provoke harms to individuals), or genetic, when they generate irreparable lesions in the offsprings' organisms. The harmful effects of ionizing radiation are described by so called dose quantities. The degree of the biological mutation of the organism is correlated with the dose ${ }^{5}$ the body is exposed to, which is characterized by the absorbed energy. BFowever, the extent of the body's damage depends not only on the abs interact in different ways with their environment, analyzing the severity of the effect, it is not enough to determine how much energy is transferred to the body by the radiation, but we also need to know what type of radiation it is. Taking into con- sideration the type of the radiation, we can then speak about an equivalent dose. Besides the type of the radiation and the energy, the various sensitivities of the various tissues are taken into account with a so called weighting factor (effective dose).

From the point of view of radiological protection, the biological effects of ionizing ra- diation can be stochastic and deterministic, based on dose-response relationships. One of the characteristics of the deterministic effect is that the damage must occur above a certain dose level, called threshold dose (the severity of the effect depends on the magnitude of the absorbed dose). It is typical of stochastic effects that they do not have a threshold dose, each dose has a given probability of biological changes and that likelihood grows in direct ratio with the increasing dose. Depending on the nature of the medical activity, the used technol- ogy and the quality of the applied materials, the employees and those who are in the scope of working can be exposed to external radiology on the whole body, on individual parts of 
the body, by inhalation, ingestion, through mucous membranes and through different injuries on their skin. As to the sources of radiation we can distinguish sealed and unsealed ${ }^{6}$ sources, which determine the exposition possibilities.

\section{Some typical uses of ionizing radiation in medical practice}

The application of the radiation formed during the decay of radioactive isotopes is typical for many areas of medicine both for diagnostic and therapeutic purposes. In this part of the article I give an overall review about them.

Nuclear medicine is a medical diagnostic, therapeutic and research activity done with unsealed radioisotopes. Its methods are based on the application of radiopharmaceuticals (isotope labelled organ-, tissue- and function-specific compounds). If we transfer these compounds into the living body - due to their chemical, biochemical specialities they can be attached to certain normal or abnormal structures thus they can be used for examining the structures and for radiation therapy. For diagnostic work those radiopharmaceuticals are used where the radiation can be detected externally with special detection equipment (such as a gamma camera). (Szilvási, 2004) A piece of the most frequently used equipment is the positron emission tomograph, also widely known as PET. The essence of the procedure is

5 See Decree No. 16/2000 (VI.8.) EüM of the Minister of Health concerning the phenomena.

6 Radioisotopes are utilized as sealed or unsealed radiation sources. We can speak about a sealed source of radiation if the radiation of the radioisotopes we wish to utilize can get from its canning into the environment, but the formation of the radiation source prevents the radioactive material from entering the environment. When radioactive material is not canned or covered in another way, i.e. radioactive substance may pollute the environment and get into human organisations, we talk about an unsealed radioactive source. (Fehér, Deme [ed.], 2010: 140)

TISZOLCZI Balázs Gergely: Protection and Safety of the Application of Radiation Sources in Medicine

that positive beta active isotopes (called markers) emitting positrons are transferred into the patient's body (typically ${ }^{18} \mathrm{~F}$, ${ }^{11} \mathrm{C},{ }^{13} \mathrm{~N}$ and ${ }^{15} \mathrm{O}$ are used) and the repartition of the materials can be detected by a PET camera through the perception of positron emission accompanying annihilation gamma rays. ${ }^{7}$

The various diagnostic X-ray procedures represent a different technology, but they are among the most commonly used methods and technologies. These are publicly known, be- cause they are the kind of technologies one can meet in everyday life very often. This may include dental X-ray, chest X-ray, mammography, computer tomography, and so forth. Part of the rays are totally absorbed in organs and another part of them can pass through the body (by passing through different tissues they also can be absorbed in varying degrees, at most they lose some of their power). The third part is scattered and changes its direction. A special X-ray film is taken beyond the studied area on which the X-rays passing through leave a sign with a chemical reaction. This is called an X-ray shadow (Németh, 2011), which helps to detect abnormalities. Although we spoke about it before, it is worth mentioning again that medical $\mathrm{X}$-ray radiation is not formed by radioactive decay. $\mathrm{X}$-rays come into existence in a special vacuum tube, and then they leave it and pass through the body. The most basic (and easily described) method of production is that electrons are accelerated; next they are made to crash into a metal target (often made of wolfram). In this metal target the electrons sud- denly slow down, and if they are at an energy level high enough, then braking X-radiation is formed. ${ }^{8}$

Angiography is slightly different from "classic" $\mathrm{X}$-ray diagnostic procedures. This is an examination method (with $\mathrm{X}$-rays) of those blood vessels that ensure the blood supply of the various organs of the body. The organs which X-rays can freely pass through (such as blood vessels) do not give an X-ray shadow. If we are curious of possible aortic stenosis and em- bolisms of different parts of blood vessels we have to inject them somehow with substances absorbing radiation. These substances are so called contrast media. Since the blood flow washes the contrast media out of the blood vessels quickly, we have to inject them directly into the studied area which can be achieved manually through catheters. The doctor can see the emerging picture under a fluoroscope or using digital images. (Szabó, 2012)

The further major use of radioactive sources is radiation therapy, which is based on the cell-killing effect of highenergy ionizing radiation. It is especially used for the treatment of various tumors. The radiation can result in damage to the genetic material in the concerned tissue (DNA), thereby the multiplication of cancer cells is reduced. Although the radiation has an adverse effect on normal tissue as well, the radiation sensitivity of cancer cells is gen- erally greater than that of intact ones, so this way a highly selective effect can be achieved. (Horváth, 2013) Numerous types of radiation therapy are known.

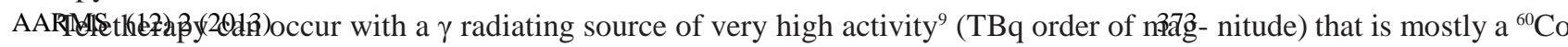
(cobalt canon), placed relatively far from the body. The radiation source is situated in a protected storage unit of the head section, which is set in the proper po- sition at the beginning of the medical treatment with mechanic control. At the end of the us-

7 http://www.meridianmc.hu/index.php?title=Amit\%20a\%20PET/CT\%20-\%20vizsg\%E1latr\%F31\%20 tudni\%20\%E9rdemes\&p=rovat\&c=45 (downloaded: 1808 2013)

8 http://hu.wikipedia.org/wiki/R\%C3\%B6ntgensug\%C3\%A1rz\%C3\%A1s (downloaded: 0108 2013)

9 Activity is the number of dissolution processes that happen in radioactive materials within a certain unit of time.

TISZOLCZI Balázs Gergely: Protection and Safety of the Application of Radiation Sources in Medicine

age it goes back into the storage unit automatically. ${ }^{10} \mathrm{~A}$ linear accelerator is a special electron accelerator developed as an 
external radiation source for patients who suffer from cancer. Electrons are accelerated with a high-frequency electromagnetic field and then maneuvered on a target (tungsten) which decelerates it, and hereby a - so called braking X-ray radi- ation is created. In practice the direct use of electrons can occur. The shape of the radiation field is designed in the head of the machine by movable collimators (beam control device).$^{11}$

First of all, the applications of brachytherapy are special from the viewpoint of radia- tion protection at places of work. Brachytherapy is executed only by using the after-loading method to reduce the radiation exposure of the personnel. After the transfer of the inactive applicators (usually tubes in small diameter and varied geometry) into the patient's body (into the ventricle, or directly into the tumor), the radioactive sealed source from the pro- tected storage of the computer-controlled device goes automatically to the position desired during the irradiation, and remains there for the period of time predefined when the irradi- ation was being planned. (Ésik, 1996: 44-48) ${ }^{60} \mathrm{Co},{ }^{192} \mathrm{Ir}$ and ${ }^{125} \mathrm{I}$ isotopes are applied to the treatment most often.

\section{Radiation protection in medicine}

The use of radiation for medical purposes started in Hungary in the early years of the $20^{\text {th }}$ century, which was followed by radiation protection only about 20 years later. To ensure that the objectives and principles of radiation protection progress, we need, above all, a proper regulatory system. Over the years, a standard system of regulation of radiation protection has evolved. For the first appearance of radiation protection standards in our country we had to wait until 1949, when the radiation protection standard finished in 1942 finally came into force. In 1952 the first health ministerial decree in radiation protection was released, it was called "Protecting Measures Concerning Medical X-ray Units". These days the Hungarian basic safety regulation is the Decree No. 16/2000 (VI.8) EüM of the Minister of Health (VHR) which was based upon the 1991 official statement of the International Commission on Radiological Protection and on the International Basic Safety Standards of the International Atomic Energy Agency. The Hungarian regulations meet those of the European Union. (Fe- hér, Deme [ed.], 2010) The above regulations are enforced by the special radiation hygiene authorities in Hungary. This special field of radiation hygiene deals with the industrial and medical application of ionizing radiation, and the radiation protection and safety of radiation workers and the population. (Fehér, Deme [ed.], 2010: 53)

The general effort of radiation protection is to defend human beings and the environment while using ionizing radiation from its harmful effects without unnecessarily restricting the activities. The radiation protection system consists of three basic principles: the justification of use, optimization, as well as the establishment of dose limits.

- Justification of medical exposure. Medical exposure shall show a sufficient net benefit, weighing the total potential diagnostic or therapeutic benefits it produces, including the direct benefits to health of an individual and the benefits to society, against the individual detriment that the exposure might cause.

\footnotetext{
10 http://www.honcology.hu/portal/page/portal/OOI/MEDICAL_ATTENDANCE/medical_departments/MD_10/ keszulekek_2012.pdf (downloaded: 0408 2013)

11 Ibid.
}

TISZOLCZI Balázs Gergely: Protection and Safety of the Application of Radiation Sources in Medicine

- Optimization of medical exposure. All doses due to medical exposure for radiodiag- nostic or interventional radiology shall be kept as low as reasonably achievable con- sistent with obtaining the required medical information, taking into account economic and social factors. For all medical exposure of patients for radiotherapeutic purposes, exposures of target volumes shall be individually planned, taking into account that doses of non-target volumes and tissues shall be as low as reasonably achievable.

- Dose limits for medical exposures. The dose limits are not applicable to the medical exposures of patients, but the optimisation of the radiation protection of patients in- cludes the application and use of diagnostic reference levels. Diagnostic reference lev- els mean dose levels in medical radiodiagnostic or interventional radiology practices, or, in the case of radio-pharmaceuticals, levels of activity, for typical examinations.

In medical practice, planning and keeping doses (diagnostic or therapeutic) of irradiation carried out on purpose for the patient's 2 (2013) good at the minimum level necessary are mainly medical tasks. So at this point we discuss "only" the possibilities of protection against expo- sures related to work ${ }^{12}$ or deriving from unwanted incidents. Of course, adequately organized protection can guarantee not only the safety of employees but the safety of those who are in the within the scope of operation and/or have resort to the services. Furthermore, data col- lection in connection with the radiation and their evaluation, and the constant monitoring of health and physical conditions of individuals are also parts of the protection as secondary pre- vention. Mainly those medical procedures are not subjects of this article that can be regarded as tertiary prevention that stop or slow down the worsening of patients' states.

While optimising protection, we have to pay attention to the scientific and technological level of the age, economic considerations, social factors, and individual sensitivity. The phys- ical defence of the radiation source against theft, unauthorized appropriation and other illegal activities means a further protective task.

The above, altogether, means that the skills and abilities of various experts from different special fields are necessary for organizing effective protection. All of these should be done despite the fact that the general rules of radiation protection cannot wholly achieve their goals due to the special system of aims and the operational features of the 
healthcare system. This job with great responsibility must be realised in a complex way, which can be achieved by realising varied organisational-administrative, personal and technological-physical condi- tions.

\section{Supervision and control by the authorities}

It is possible to apply radiation sources exclusively in the way it is determined in the pro- visions of law and under official supervision. Equipment generating ionizing radiation used for medical purposes (such as $\mathrm{X}$-rays, accelerators, etc.), ionizing radiation emitting materi- als (radioactive materials), and activities relating to these naturally belong to this regulated group.

The supervisor tasks of first instance authorities have been carried out by seven regional Radiation Hygiene Centres working as parts of the Capital- and County Government Offices in the new governmental system since 1st January 2011. The radiation-protection authority

12 All the radiation exposure that may reach employers while they are working.

TISZOLCZI Balázs Gergely: Protection and Safety of the Application of Radiation Sources in Medicine

of second instance is the Office of Chief Medical Officer (OCMO), which belongs to the National Public Health and Medical Officer Service (NPHMOS). The NPHMOS consists of the OCMO and the national institutes under its leadership. One of these national institutes is "Frédérich Joliot-Curie" National Research Institute for Radiobiology and Radiohygiene, which is a special institute for radiation protection belonging to the NPHMOS, and the only institute in the country that deals with radiation protection at places of work as its main job.

In their framework, Radiation Hygiene Centres issue licenses, at first level one, for the storage, use and application of radioactive materials, the foundation, production, operation, reorganisation, repair, terminating of operation, dismantling of non-nuclear facilities and equipment, furthermore, the operation, maintenance, and terminating the operation of equip- ment creating ionising radiation. (EüM, 2000) The Radiation Hygiene Centres supervise the facilities and activities with legal permission at a frequency determined by law (taking the dangers of the facilities and activities into consideration when setting the frequency), for example places of work with $\mathrm{X}$-ray therapy, teletherapy, are checked after loading and the accelerators are checked annually. When controlling, the authority makes sure that the dose limits are kept, employees' medical check-ups are done, employees, patients, environmental protection and training are secured and the other rules depending on the characters of ac- tivities are observed. It also measures the above with gadgets. If deficiencies are revealed, it takes the necessary measures to terminate them. ${ }^{13}$ The OCMO (based on the opinion of NRIRR ${ }^{14}$ ) qualifies and permits equipment emitting ionising radiation or containing a radio- active source of radiation and personal protective equipment from the viewpoint of radiation protection. The equipment/protective equipment may only be distributed and applied if it has the radiation protection qualification. (EüM, 2000)

The equipment forming ionising radiation is work equipment and as such, they prove to be dangerous implements according to Act XCIII of 1993 on Labour Safety. Workplaces us- ing ionising radiation are determined as dangerous workplaces. The main rule is that the em- ployer orders the operation of dangerous facilities, places of work, equipment and technology in writing. Moreover, he supervises dangerous technologies and dangerous work equipment from a safety point of view for maintaining safe technological conditions. However, the sphere of authority of occupational safety authority does not include the radiological hygiene duties related to labour. (OGY, 1993) Another interpretation is that the above tasks cannot be qualified as radiological hygiene ones, but as occupational safety ones as concerns radiation safety. At the same time, it is a practical experience that the occupational safety authority does not require or check occupational safety commissioning or periodical supervisions since the permissions issued by the Radiation Hygiene Centre and the check-ups periodically done can be regarded as equivalent to them, from a safety viewpoint. Certainly, the conditions of safe work not endangering health have to be assured at working places with ionising radiation. That is why employers' other occupational safety duties, such as risk assessment of the activities, the ergonomic suitability of working places, etc. still remain and they are examined by the occupational safety authority.

The appliers of radioactive material locally records the whereabouts, physical and chem- ical features and the 376 acities related to the radioactive materials in their ownership and they AARMS (12) 2 (2013)

13 http://www.antsznydr.hu/index.php/sugaregeszseguegyi- decentrum (downloaded: 1508 2013)

14 "Frédérich Joliot-Curie" National Research Institute for Radiobiology and Radiohygiene (abbreviated in

Hungarian: OSSKI)

TISZOLCZI Balázs Gergely: Protection and Safety of the Application of Radiation Sources in Medicine

serve the central register with data. (OGY, 1996) In Hungary the organisation of atomic-en- ergy supervision is the Hungarian Atomic Energy Authority (HAEA). HAEA keeps a central record of radioactive materials, which contains their whereabouts, physical and chemical features, the appliers of atomic energy and the activities related to them.

\section{Appliers'obligations}


The VHR prescribes for the employer the obligation of setting up a radiation-protection service and nominating a person in charge of radiation protection. Among others, it is the job of the service of radiation protection to check whether the radiation-protection condition of the direct surroundings and the area of the facility and of the personnel working there meets the requirements set by provisions of law, standards and internal rules. The service of radia- tion protection consists of at least one local radiation protection officer and his deputy. The organization and the operation of the service of radiation protection are under the supervision of the Radiation Hygiene Centre. One of the most important jobs of radiation protection personnel is to make the Workplace Radiation Protection Regulations which is approved by the Radiation Hygiene Centre. ${ }^{15}$ The plan for the prevention of accidents and measures (workplace emergency plan) is a compulsory element of the rules and it has to involve the order of preventing possible accidents, their handling, the possibilities of arrangements and obligations. The possibility of extraordinary events has to be estimated depending on the applied materials and technology and the character of possible events have to be determined. Accordingly, an individual plan of accident prevention and arrangements have to be worked out. Care has to be taken to teach the contents of this plan and have it practised.

The employees of work places with a radiation hazard are divided into two categories from the aspect of their potential exposure. The employees in Class " $\mathrm{A}$ " are those in whose case there is a chance that their annual effective dose exceeds the value $6 \mathrm{mSv}$. Class " $\mathrm{B}$ " is for all the other workers. It is obligatory to check each employee in Class "A" with a personal dosimeter for radiation exposure coming from an outside source. The gadgets necessary for the check-up are obtained and issued to employers by NRIRR. Employers make sure via the service of radiation protection that the employees whose radiation exposure has to be checked by the authorities on a regular basis should get the dosimeters and wear them during the whole worktime and activity. Those who display activity are obliged to wear them. If they do not do so in spite of a warning or they do not use them properly, the employer should for- bid them to do work. The service of radiation protection is obliged to register the dosimeters.

In some special cases, it has to be made sure that the risk is kept on a level as low as possible from the viewpoint of the population, the users, and the environment concerned. It is such a precaution that when diagnostic or therapeutic treatment is applied with radioactive isotopes, the patients - before leaving the medical institution - have to be given written information on the methods of reducing the radiation exposure on people who get into touch with the patients and the risk of the treatment.

TISZOLCZI Balázs Gergely: Protection and Safety of the Application of Radiation Sources in Medicine

\section{The personal conditions of safe application}

Only those persons may show activity in the area of ionizing radiation who have participated in an examinationobligatory training and retraining of radiation protection, ${ }^{16}$ and passed the exam. We can distinguish three levels of training of radiation protection: those who work in a sphere connected with an activity of radiation danger, but do not work with a radiation source, are obliged to attend a training of basic-level radiation protection. The employees who work in the range of action of radiology and medicine, employing ionising radiation, including the appliers of sealed and unsealed radiation sources, handle the radiation source independently and/or supervise a range of action like that or work in the health-care system applying an ionising source of radiation occasionally, have to take part in a course of radia- tion protection on an extended level. Those who work in a sphere with the risk of increased exposure of ionising radiation, either as independent workers or as leaders or as supervisors, etc. need comprehensive training

Act XCIII of 1993 on Labour Safety declares that workers in Hungary have the right to safe and healthy places of work. It is obvious that the surplus exposition at workplaces with radiation is the biggest source of danger, which can be the consequence of operation or that of an unexpected event. In harmony with the Act above, the VHR ordains that employees' annual radiation exposure from all sources may not exceed the dose limit value that is set by the safety rule relating to it. (EüM, 2000) Provided an employer creates the personal and material conditions of working ordained in statutory provisions and standards of radiation protection, and the general and local regulations of radiation protection are kept, then the radiational health-care risk will not exceed the level of risk in other branches regarded as secure

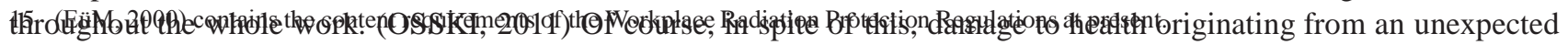
event cannot be excluded. Therefore you must make sure during the application that the risk of unexpected events 3h8uld decrease, their forma- tion should be preventable, their results shotAdRMSsy effects of possibly escaping radioactive material and ionising radiation should be reducable to the level as low as possible that can be reasonably achieved.

As secondary prevention, besides the exclusion of endangering factors or their reduction to the reachable level as low as possible, the working conditions, the preliminary and regular medical surveillance of employees' health, job prohibitions and the occasional aggravation of dose limits play an important role in prevention. On opinions about the suitability to the scope of activity, employees are obliged to participate in a pre - and periodical employment medical examination so it can be determined, what strain the load/stress caused by an activity done in a certain scope of work and at a given place of work means for the person concerned. Before one is set to work, it is necessary to apply the preemployment medical examination on him or her. Until suitability is judged or in the case of unfitness, the employee 
cannot be employed in the set scope of work. In the case of employees exposed to ionising radiation, i.e. those working with medical X-ray machines and accelerators, those who do oncological ray treatment, furthermore, those employed in isotope-laboratories Type "C" have to submit to annual medical checkups. A final examination has to be done after a four-year exposition to ionising radiation at the end of the activity or labour relation. Another limitation is that

TISZOLCZI Balázs Gergely: Protection and Safety of the Application of Radiation Sources in Medicine

pregnant women or women who have given birth to a baby shortly before and juvenile work- ers may not be employed at work places where they could be exposed to ionising radiation. (NM, 1998) In the case of increased exposition an outof-turn examination is compulsory. The medical checkups of those employed in organised employment (with exceptions deter- mined by law) is on the first level done by the occupational physician authorized to provide occupational health service who has a contract with the employer. In dealing with risk, it is an important principle that the introduction of a measure reducing a certain risk cannot cause any other kind of extra risks or risks that occur in another place, for example frequently used personal protective equipment, especially lead aprons for protection against radiation, in var- ious places of work with X-ray in health care. When wearing them, you should reckon with secondary risks, such as illnesses of the bones and the muscular system. The surplus risks occurring when wearing personal protective equipment have to be taken into consideration when the person's medical suitability to work is judged. Besides work done sitting for a long time means unilateral burdening in the course of several diagnostic procedures and at places of work with monitors. The biological effects of radiation are determined basically by the dose. The two essential factors modifying the effects of radiation, the kind of radiation and the tissue sensitivity, though temperature also needs to be taken into account. Above normal body temperature, human cells become more sensible to radiation. They especially make use of it for improving the effectiveness of various radiation therapies. Besides the temperature, the individuals' physiological condition also influences the effects of radiation. ${ }^{17}$ In places of work, not only the check of the radiation level of the surroundings is important, but also the monitoring of the air condition, the formation of appropriate ergonomic conditions, their regular supervision, suitable time to relax, furthermore, proper meals and social conditions for employees. Beyond working time, organized recreational programmes and facilities may also help to maintain the proper physiological state. At workplaces with radiation, it is also important to inform workers about the risks of personal habits (e.g. the effects of smoking, al- cohol, etc) in the framework of work- and radiation protection training related to the activity.

\section{The technological possibilities of radiation protection}

National standards involve the formation of various places of work with radiation hazard and the regulation of working processes in detail. The standards describe the requirements of the architecture and the mechanical systems of workplaces with radiation danger, the unexpected events, furthermore, the questions of the realisating radiation protection. It is regarded to be a general principle that collective protection has a privilege in comparison with personal, when protection is planned. An area in workplaces with radiation danger that is supervised in an analogous way according to the regulations of VHR has to be indicated. Those area of work are regarded as controlled areas, where the annual individual radiation exposure deriving from the activity may exceed the effective dose of $1 \mathrm{mSv}$ and in the case of the crystalline lens, the skin and the limbs, one-tenth of the relating value dose limits, and where the spread-ing of radioactive pollution and the possibility of radiation exposure have to be limited. The order sets the requirements of creating controlled areas and the rules of motion within

17 The content of this chapter is based on a note from the homepage of Paks Nuclear Power Plant. http://www.atomeromu.hu/download/3217/Alapfokozatu_sugarvedelmi_ismeretek_jegyzet.pdf (downloaded: 0108 2013)

TISZOLCZI Balázs Gergely: Protection and Safety of the Application of Radiation Sources in Medicine

them, entering and doing work there. According to VHR the Workplace Radiation Protection Regulation determines the 16 (EüM, 2000 contains the detailed rules requirements and the condition concerning examiners at present.
system of safety and security requirements to be minimally kept relating to the area supervised (the working area where it is not necessary to keep the special radiation protection measures ordained for the controlled area). However, regular AARMS over the (2013)ervised area has to be exercised. (EüM, 2000)

As it was mentioned before, brachytherapy is exclusively done with the after-loading method in order to reduce the radiation exposure on the personnel, the staff carrying out the intervention should not be affected by the radiation, and the apparatus can be controlled from another room.

In teletherapy the most important radiotherapy sources are the linear accelerators (LIN- AC). Besides the LINACs, there are cobalt irradiators too. The radiation of high energy irradiators cannot be absorbed in patients, it goes through them. The primary, scattered and leakage radiation reach the walls and scatter into the maze. The bunker walls and the entrance maze have to be planned to resist these radiation.

During some working processes, such as traumatological and other operations, or in the case of mobile $\mathrm{X}$-ray machines, in hospital wards, when the photos are not taken in a place created for this purpose and screened, that is why 
scattered radiation reaching the crew may occur more easily and in larger doses. In sick-wards they often apply lead plates of various sizes with a suitable support to protect the other patients during taking mobile $\mathrm{X}$-ray photo- graphs.

Reducing the time of exposition to a level as low as possible and increasing the distance between the radiation source and the employer (time- and distance protection) is not always a technological one, but it is a collective protective measure. The aim of applying the tools of an isotope laboratory kept on compulsory store, i. e. tweezers, forceps, is also to enlarge the distance between the radioactive source and the hand/body so the dose affecting the employ- ers can be decreased to a fragment. In the case of unsealed isotopes, actions accompanied by crumbling and evaporation may be carried out in local exhaust boxes.

It is also an important principle of occupational safety that dangerous things should be replaced by harmless or less dangerous ones so we have to endeavour to use smaller activity radiation sources.

When collective technological protective arrangements cannot be applied or their effi- ciency is not suitable, it is reasonable to use personal protective equipment against various radiation. Their protective abilities are given in so-called lead equivalents that equal the pro- tective ability of the lead that is the same size as the indicated value (thickness in $\mathrm{mm}$ : 0.25 ;

0.5 ; 1 ; etc.) The most frequently applied protective equipment (mainly in places of work with X-ray and some places with isotopes) are lead coatings, lead aprons, lead collars for protect- ing thyroid glands, lead glasses and mouth-masks to prevent the inner radiation exposure deriving from crumbling and evaporation. Besides, some injectors for injecting radioactive isotopes are also coated with lead to protect the employees' hands and fingers. Choosing the proper equipment and protection level requires great expertise. Determining the order of us- ing personal protective equipment is a special occupational safety activity.

The continuous application of the achievements of technological development is another important requirement for employees' safety. Because of X-raying during heart catheteriza- tion, the radiation exposure of those who are in the room is added up in the course of daily examinations, and it is quite significant even though it is obligatory to wear lead aprons.

TISZOLCZI Balázs Gergely: Protection and Safety of the Application of Radiation Sources in Medicine

These days we can improve the safety of the procedure with the help of robot technology. With its application, medical specialists can supervise the catheter from a laboratory further away from patients' beds. With this procedure, the radiation exposure of the doctors doing the operations can be decreased significantly compared to the traditional technology. Besides minimizing the radiation dose suffered by employees, the procedure reduces the frequency of articular diseases due to wearing a lead apron. (MTI, 2012)

Unusual crumbling, evaporation, splashes and physical injuries, e. g. a pin-prick during injecting contrast material, the consequences of accidents, technological deficiencies and irregular work (for example lack of an exhaust box, improper exhausting, the bad technolog- ical state of the place of work, lack of personal protective equipment, etc.) may happen when the job is done with unsealed radiation sources. Therefore you must keep an emergency set in stock in the place of the activity applying radioactive preparations. One must assemble the emergency set taking into consideration the technological processes, the employees' number, the character and danger of the applied material.

One must give special attention to the proper operation and maintenance of the collective and personal protective equipment as they are very important for the employees' protection throughout their lifetime.

\section{Summary}

Creating working conditions that are safe and do not endanger health in connection with the application of ionizing radiation in health care means quite complicated tasks and obligations to the employees whose main orders concerning the application of radiation sources and radiation protection are determined in the Workplace Radiation Protection Regulation. At the same time, almost all internal regulations of health and security at work have a chapter on radiation (regulations of occupational safety, fire protection, etc.) The well-co-ordinated work of several experts and special fields is needed for taking protective measures and a far-reaching authority and supervising system takes care of keeping the rules and making the realization easier. Naturally, what has been written down here is only of summarising

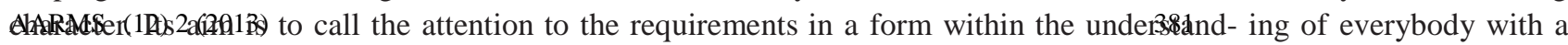
high-level knowledge of the given technology and the professional requirements of radiation protection, and the widespread application of the legal and standard rules redownloaded in this writing are necessary for realising complex protection.

\section{References}

ÉSIK O. (1996): A rosszindulatú daganatok sugárterápiája. Háziorvos Továbbképző Szemle Vol. 1 Issue 1, pp. 44-48., online, ISSN 1219-8641 http://sunrise.sote.hu/htsz/esikolga.htm (downloaded: 0408 2013)

EüM, (2000): 16/2000. (VI. 8.) EüM rendelet az atomenergiáról szóló 1996. évi CXVI. törvény egyes rendelkezéseinek végrehajtásáról. http://net.jogtar.hu/jr/gen/hjegy_doc.cgi?docid=A0000016.EUM (downloaded: 0408 2013)

FEHÉR I., DEME S. [szerk.] (2010): Sugárvédelem. Budapest: ELTE Eötvös Kiadó, ISBN 9789632840802 
TISZOLCZI Balázs Gergely: Protection and Safety of the Application of Radiation Sources in Medicine

HORVÁTH B. (2013): Mit kell tudni a sugárterápiáról?

http://www.webbeteg.hu/cikkek/daganat/3881/mit- kell- tudni- a- sugarterapiarol (downloaded: 0108 2013)

MTI (2012): Szivkatéterezés robotkarokkal. http://www.webbeteg.hu/cikkek/sebeszet/13134/ szivkateterezes-robotkarokkal (downloaded: 1708 2013)

MVM PAKSI ATOMERŐMÜ Zrt. (2013): Sugáregészségügyi ismeretek. Paks http://atomeromu.hu/download/199/ug\%C3\%A1reg\%C3\%A9szs\%C3\%A9g\%C3\%BCgyi\%20 ismeretek.pdf (downloaded: 0108 2013)

NÉMETH Á. (2011): Röntgen vizsgálat. http://www.webbeteg.hu/cikkek/adattar/12212/rontgen- vizsgalat (downloaded: 1508 2013) NM"18 (1998):

33/1998. (VI. 24.) NM rendelet a munkaköri, szakmai, illetve személyi higiénés alkalmasság orvosi vizsgálatáról és véleményezéséröl. http://net.jogtar.hu/jr/gen/hjegy_doc.cgi?docid=99800033.NM (downloaded: 0108 2013) OGY19 (1993): 1993.

évi XCIII. törvény a munkavédelemröl a végrehajtásáról szóló 5/1993. (XII. 26.) MüM rendelettel egységes szerkezetben. http://net.jogtar.hu/jr/gen/hjegy_doc.cgi?docid=99300093.TV\&celpara=\#xcelparam (downloaded: 0408 2013)

OGY (1996): 1996. évi CXVI. törvény az atomenergiáról. http://net.jogtar.hu/jr/gen/hjegy_doc. cgi?docid=99600116.TV\&celpara=\#xcelparam (downloaded: 0108 2013)

ORSZÁGOS “FRÉDÉRIC JOLIOT-CURIE” SUGÁRBIOLÓGIAI ÉS SUGÁREGÉSZSÉGÜGYI KUTATÓ INTÉZET (2011): Izotópos munkavédelmi szabályzat a helyes munkavégzés gyakorlata a nyitott radioaktív készitményeket alkalmazó munkahelyeken. Budapest: OSSKI, ISBN 978-963-87459-7-2 http://www.osski.hu/kiadvanyok/izotoposmh/IzotoposMunkavedelmiSzabalyzat_OSSKI_MU_2011.pdf (downloaded: 0708 2013)

SZABÓ N. (2012): Érfestés. http://www.hazipatika.com/vizsgalatok/erfestes/14 (downloaded: 1508 2013)

SZILVÁSI I. (2004): A nukleáris medicina a járóbeteg szakellátásban. IME - Az egészségügyi vezetők szaklapja, January 2003 Vol. 2. Issue 10, ISSN 1789-9974 http://www.imeonline.hu/article/188/47.pdf (downloaded: 04 08 2013)

Further reference not indicated in the text: Proposal for a Council Directive laying down basic safety standards for protection against the dangers arising from exposure to ionising radiation; Council of the European Union, Brussels, 30052012 http://ec.europa.eu/energy/nuclear/radiation_protection/doc/2012_com_242.pdf (downloaded: 2208 2013) 